\title{
食品製造副産物の肥育豚における利用性に関する研究
}

\section{2. 豆腐粕サイレージ給与による発育および体脂肪に及ぼす影響}

\author{
丹羽美次・中西五十 \\ 日本大学農獣医学部, 神奈川県藤沢市 252
}

（1994 年 9 月 20 日受付）

\begin{abstract}
要 約 豆腐粕の有効利用を促進するため, 豆腐粕に $13.7 \%$ の大麦と $0.7 \%$ のプレミックスを加えて 調製したサイレージを肥育豚に給与して消化試験，ならびに肥育試験を実施するとともに，肥育試験終 了後に脂肪融点および脂肪酸組成を調べた。体重 $50 \mathrm{~kg}$ のW 交雑種を用い，5 日間の消化試験を行っ た結果, 豆腐粕サイレージ給与区の NFE，粗蛋白質および粗脂肪の消化率はトゥモロコシを主体とした 対照区と比較して大きな差はなかったが，粗繊維の消化率は有意に高かった。肥育試験は $\mathrm{LW} \cdot \mathrm{H}$ 交雑 種を用いて 3 群を設け約 16 週間にわたって実施し, 飼料給与は 1 日 2 回の制限給餉とした。 1 群は対照 区飼料を全期間給与した。 2 群は $1 \sim 12$ 週は豆腐粕サイレージを $100 \%, 13 \sim 16$ 週は対照区飼料を給与 した（豆腐粕サイレージ 1 区）。3 群では 1 3 週に豆腐粕サイレージを $100 \% ， 4 １ 4$ 週の間は豆腐粕サ イレージと対照区飼料の大豆粕を大麦に代えた飼料を $50 \%$ (乾物換算)ずつ, $15 \sim 16$ 週には対照区飼料 を $100 \%$ 給与した（豆腐粕サイレージ 2 区）。肥育試験では, 豆腐粕サイレージ 1 区は全飼料の $66 \%$, 豆 腐粕サイレージ 2 区では $47 \%$ をサイレージで代替した。増体日量ならびに飼料要求率はどの期間にお いてあ 3 区間に差は認められなかった。また，サイレージの嘹好性は極めて良好であった。背脂肪およ び腎臟周囲脂肪の融点を測定した結果，サイレージ給与区は対照区に比べ，いずれの部位であ有意に低 いか低い傾向を示した。脂肪酸組成では, リノール酸およびリノレン酸は有意に高く, また，オレイン 酸およびパルミチン酸は低かった。
\end{abstract}

緒

言

近年, 食品製造副産物の廃棄量が激增している。特に, 豆腐粕のような高水分の副産物は変敗し易いことから廃 棄率も高く, 公害の発生源になっている例も多い。

豆腐粕は製造過程において水溶性成分の多くが抽出さ れた残渣であるが，なお可消化養分に富み，新鮮なもの は家畜の㖺好性も高い。生豆腐粕は変敗しやすいが，産 出後すみやかに的確な方法によって眝蔵することによ り, 飼料としての利用あ促進されると考えられる。著者 らは資源の有効利用之廃棄量の減少による環境保全への 対応として，豆腐粕をサイレージに調製する眝蔵法につ いて報告しだ)。この豆腐粕サイレージ（以下サイレー ジとする）は不飽和脂肪酸含量の高い脂肪を比較的多量
に含有しており, 肉豚への給与により肉質, 特に体脂肪 に対する影響む考えられる。そのため, サイレージの利 用を図るためには豚に対する栄養価や肉質等への影響を 明確にする必要がある。以上のことから肥育豚にサイ レージを給与し，消化試験，肥育試験を実施するととむ に背脂肪厚, 脂肪酸組成への影響について調查した。

\section{材料および方法}

供試飼料 : 供試飼料の配合割合は表 1 に示すとうりで あり, 本学部付属農場慣用の肥育飼料之豆腐粕サイレー ジを用いた。サイレージは豆腐粕に大麦を $13.7 \%$ ，カル シウム剤・食塩・ビタミン・微量ミネラル剤混合物を $0.7 \%$ 加え 3 週間以上眝藏したものを用いた。調製され たサイレージは $\mathrm{pH} 3.7 \sim 3.9$, 乳酸含量 1.5 2.2\%（新鮮

Research on the utilization of food by-product to growing and finishing pigs

2. The effects of tofu cake silage feeding on growth and body fat

Y. NIWA and G. NAKANISI

Department of Animal Science, Nihon University, Fujisawa-shi, 252 
物中）と良質であった。また，肥育試験ではサイレージ の蛋白質含量が高いことから慣用肥育飼料の大豆粕を大 麦で代替した試験飼料も併せて使用した。

供試動物：消化試験には本学部付属農場で生産された 体重約 $50 \mathrm{~kg}$ の LW 交雑種肥育豚 6 頭（慣用肥育飼料区 3 頭, サイレージ区 3 頭) を使用した。供試豚は代謝ケー ジで単飼し, 飼料は 1 日に乾物換算 $1 \mathrm{~kg}$ を朝夕 2 回 500 $\mathrm{g}$ ずつ給与し, 水は自由に飲水させた。また, 試験期間 は予備試験 5 日間, 本試験 5 日間の全糞採取法により,

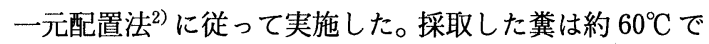
24 時間乾燥し, 風乾後粉砕して分析に供した。

肥育試験は $\mathrm{LW} \cdot \mathrm{H}$ 交雑種肥育豚 12 頭（開始時平均 体重 $28.6 \pm 0.4 \mathrm{~kg}$ ）を使用し, 性別, 体重等を考慮して 3 区に分けた。飼養方法は $3.6 \mathrm{~m} \times 2.7 \mathrm{~m}$ の豚房に 1 群 4 頭 で群飼し, 飼料は制限給餌法により朝夕 2 回等量給与し た。体重測定は 7 日毎に実施し，その結果をむとに日本 飼養標準 ${ }^{3)}$ の肥育豚に対する風乾飼料量を基準として飼 料給与量を決定した。肥育試験における飼料の給与法は 表 3 に示すとうり, 全期間慣用肥育飼料を給与した対照 区, 試験開始（1 週）から 12 週までサイレージのみを給 与し, その後出荷まで慣用肥育飼料を給与した豆腐粕サ イレージ 1 区および試験開始時より 3 週間をサイレージ
のみ，4〜14 週をサイレージと試験用飼料（乾物換算で 各 50\%)，15 週から出荷までは対照区と同じ慣用肥育飼 料を給与した豆腐粕サイレージ 2 区を設けた。試験期間 は 16 週間で, 試験終了後屠殺し, 24 時間冷蔵庫内で放 冷後豚産肉能力検定基準4) に従い, 背脂肪厚を測定した。 また, 背脂肪, 腎臓周囲脂肪を採取し脂肪融点および脂 肪酸組成を調べた。

分析・測定法 : 一般成分の分析は全て常法 ${ }^{5)}$ によっ た。体脂肪の脂肪酸組成は約 5 倍量の無水硫酸ナトリウ ムと共に磨砕後クロロホルムで抽出, 飼料はクロロホル ム・メタノール溶液で脂質を抽出して溶媒を除去後, 0.5 $\mathrm{N}$ ナトリウムメチラートでメチル化し, ガスクロマトグ ラフで測定した。使用した機種はHEWLETT PACKARD 製 $5890 \mathrm{~A}$ ，カラムは J\&W 製 DB-W AX 15 $\mathrm{m} \times 0.53 \mathrm{~mm}$, 運転条件はカラム温度 $160^{\circ} \mathrm{C}$ から毎分 $3^{\circ} \mathrm{C}$ で $200^{\circ} \mathrm{C}$ まで昇温, 注入口温度 $250^{\circ} \mathrm{C}$, 検出器は FID, 検出器温度 $270^{\circ} \mathrm{C}$, キャリアーガスとしてへリウ ムを使用した。得られたクロマトグラフの相対保持時間 から C14:0 C16:0 C16:1 C18:0 $\mathrm{C} 18: 1$ C18: $2 \mathrm{C} 18: 3$ の各脂肪酸を同定し，これらの合計を $100 \%$ として組成を算出した。脂肪融点は採取した脂肪を細切 し, $100^{\circ} \mathrm{C}$ の恒温器中で濾紙を用いて加熱抽出を行い,

表 1. 飼料の配合割合

Table 1. Composition of diets

\begin{tabular}{|c|c|c|c|}
\hline & & $\%(\mathrm{DM} \%)$ & 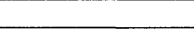 \\
\hline & Control diet & Tofu cake silage & $\underset{\text { diet }}{\text { Experimental }}$ \\
\hline Maize & 73.3 & & 73.3 \\
\hline Soybean meal & 12.0 & & - \\
\hline Barley & 10.0 & $13.7(41.9)$ & $22.0^{\circ}$ \\
\hline Tofu cake & - & $85.6(55.9)$ & - \\
\hline Fish meal (CP 60\%) & 2.6 & & 2.6 \\
\hline $\mathrm{CaCO}_{3}$ & 0.7 & ) & 0.7 \\
\hline $\mathrm{Ca}_{3}\left(\mathrm{PO}_{4}\right)_{2}$ & 0.7 & & 0.7 \\
\hline $\mathrm{NaCl}$ & 0.4 & (2) & 0.4 \\
\hline Trace mineral premix ${ }^{1)}$ & 0.1 & $0.7(2.2)$ & 0.1 \\
\hline Vitamin A, D, E premix ${ }^{2)}$ & 0.1 & & 0.1 \\
\hline Vitamin B premix ${ }^{3)}$ & 0.1 & 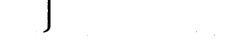 & 0.1 \\
\hline
\end{tabular}

1) Trace mineral premix supplied (per $\mathrm{kg}$ of diet): Mn $80 \mathrm{mg}, \mathrm{Zn} 50 \mathrm{mg}, \mathrm{Fe} 6$ $\mathrm{mg}, \mathrm{I} 1 \mathrm{mg}, \mathrm{Cu} 0.6 \mathrm{mg}$.

2) Vitamin A, D, E, premix supplied (per $\mathrm{kg}$ of diet) : Vitamin A 10000 I.U., vitamin $D_{3} 2000$ I.U., dl- $\alpha$-tocopherol $10 \mathrm{mg}$.

3) Vitamin B premix supplied (per $\mathrm{kg}$ of diet) : thiamine $1 \mathrm{mg}$, riboflavin $7 \mathrm{mg}$, pyridoxine $\cdot \mathrm{HCl} 0.5 \mathrm{mg}$, pantothenic acid $11 \mathrm{mg}$, nicotinic acid $6 \mathrm{mg}$, choline chloride $58 \mathrm{mg}$. 
1995,3 月

上昇融点法により測定した。

\section{結果および考察}

消化試験の結果は表 4 に示すとうりである。サイレー ジ区の粗蛋白質と NFE の消化率は対照区に比べ若干低 く, 粗脂肪はやや高かったが，いずれも有意差は認めら れなかった。サイレージ区は粗繊維の消化率が対照区に

表 2. 供試飼料の化学的組成 (\%)

Table 2. Chemical composition of diets (\%)

\begin{tabular}{lrc}
\hline \hline & Control diet & $\begin{array}{c}\text { Tofu cake silage } \\
(\text { DM } \%)\end{array}$ \\
\hline Moisture & 11.6 & $68.4(-)$ \\
Crude protein & 15.7 & $6.8(21.5)$ \\
Crude fat & 3.7 & $2.9(9.2)$ \\
NFE & 62.7 & $17.1(54.1)$ \\
Crude fiber & 2.5 & $3.2(10.1)$ \\
Ash & 3.9 & $1.6(5.1)$ \\
\hline Fatty acid & & \\
C 14 & 0.8 & 0.2 \\
C 16 & 15.2 & 12.7 \\
C 16-1 & 1.1 & 1.0 \\
C 18 & 3.4 & 4.2 \\
C 18-1 & 29.3 & 23.5 \\
C 18-2 & 47.4 & 50.9 \\
C 18-3 & 2.8 & 7.5 \\
\hline
\end{tabular}

日豚会誌 32 巻 1 号

比べ有意 $(\mathrm{P}<0.05)$ に高い值を示した。その理由は明確 ではないが，対照区飼料とサイレージ中の粗繊維では異 なる成分を含有しているためと考えられる。さらに，サ イレージ区の粗脂肪の消化率は対照区よりわずかに高い 值を示した。これは, サイレージ中の粗脂肪含量が高 かったため内因性物質の影響が少なかったこと，および サイレージ中に含まれる乳酸の一部が粗脂肪として定量 されたためと推察された。

肥育試験において給与した全飼料における豆腐粕サイ レージの割合は豆腐粕サイレージ 1 区で $66 \% ， 2$ 区では 47\%（豆腐粕としてそれぞれ $37 \%$ および $26 \%$ ）と高く, サイレージは豚の嗜好性あ良好であった。試験期間中の 1 日増体量, 飼料摂取量および飼料要求率を表 5 に示し た。1 3 週における 1 日増体量は豆腐粕サイレージ 1 , 2 区がとあに対照区を超える值となり，4～12 週におい ても豆腐粕サイレージ 1 区は対照区とほぼ同等の増体量 を示した。豆腐粕サイレージ 1 区および 2 区とあ各々 12 週および 14 週以降の対照区飼料への切替にとあない若 干の発育停帯が観察された。これは, サイレージが高水 分であるため, その給与により消化管内容物重量の増加 をあたらし体重が増すあのの, 飼料の切替に伴って消化 管内容物量が減少することから見掛け上，増体が停帯す るものと考えられる。全期間における 1 日増体量は対照 区の $0.75 \mathrm{~kg}$ に対し, 豆腐粕サイレージ 1 区は $0.72 \mathrm{~kg}$, 豆腐粕サイレージ 2 区は $0.73 \mathrm{~kg}$ で, 有意差は認められ なかった。また，全期間の飼料要求率は対照区 3.13 , 豆

表 3. 肥育試験の設定

Table 3. Design of fattening trial

\begin{tabular}{|c|c|c|c|c|}
\hline Week & $1 \sim 3$ & $4 \sim 12$ & $13 \sim 14$ & $15 \sim 16$ \\
\hline Control & \multicolumn{4}{|c|}{ Control diet $100 \%$} \\
\hline Tofu cake silage 1 & \multicolumn{2}{|c|}{ Tofu cake silage $100 \%$} & \multicolumn{2}{|c|}{ Control diet $100 \%$} \\
\hline Tofo cake silage 2 & $\begin{array}{c}\text { Tofu cake } \\
\text { silage } 100 \%\end{array}$ & \multicolumn{2}{|c|}{$\begin{array}{c}\text { Experimental diet } 50 \% \\
\text { Tofu cake silage } 50 \%\end{array}$} & $\begin{array}{c}\text { Control } \\
\text { diet } 100 \%\end{array}$ \\
\hline
\end{tabular}

表 4. 飼料の消化率

Table 4. Effect of tofu cake silage feeding on digestibility in growing pigs

\begin{tabular}{lcccc}
\hline & Crude protein & Crude fat & NFE & Crude fiber \\
\hline Control diet & $81.1 \pm 0.6^{1)}$ & $77.3 \pm 2.0$ & $91.1 \pm 1.4$ & $40.9 \pm 2.9$ \\
Tofu cake silage & $79.3 \pm 0.9$ & $79.1 \pm 1.3$ & $87.9 \pm 1.2$ & $56.7 \pm 1.8^{*}$ \\
\hline
\end{tabular}

1) Values are means \pm SEM for 3 pigs.

*, Significantly different from the control at $\mathrm{P}<0.05$. 
腐粕サイレージ 2 区 3.15 と同程度であり, 12 週間にわ たりサイレージのみを給与した豆腐粕サイレージ 1 区に おいてもほとんど違いはなかった。

サイレージ給与が背脂肪の厚さに及ぼす影響を表 6 に 示した。各部位とも豆腐粕サイレージ1区は有意に厚 かったが, 豆腐粕サイレージ 2 区では差は認められな かった。その理由は明確ではないがサイレージ醱酵の過 程で一部のアミノ酸が分解され, 必須アミノ酸組成に偏 りが生じた可能性もある。また, MATEOS ら おいて飼料への大豆油添加により非脂肪性成分の代謝工 ネルギー効率が改善されたと報告している。本試験で使 用したサイレージは豆腐粕由来の粗脂肪を多く含有し, 豚においても MATEOS らの報告と同様の効果が生じた
結果, 背脂肪厚が増加したと考えられる。一般に飼料中 に添加された油脂は $\mathrm{NFE}$ 等に比べ体脂肪として蓄積さ れやすく ${ }^{7,8)}$ その脂肪酸組成や融点に影響を及ぼすこと が報告 ${ }^{9 \sim 11)}$ されている。枝肉の 3 部位から採取した脂肪 の融点を測定した結果を表 7 に示した。対照区に比べサ イレージ給与区は全般に脂肪融点が低く, 豆腐粕サイ レージ 1 区の背脂肪内層を除きいずれも有意差（P< 0.05) が認められた。また, 豆腐粕サイレージ 1 区は腎臓 周囲脂肪の融点について対照区との間に有意差 $(\mathrm{P}<$ 0.05）が認められたが，同時に豆腐粕サイレージ 2 区と の間では有意 $(\mathrm{P}<0.05)$ に高い值を示した。入江および 藤谷 ${ }^{11)}$ は飼料への油脂添加が脂肪融点に及ぼす影響に ついて，腎臓周囲脂肪は背脂肪に比べ影響を受けやすい

\section{表 5. 発育増体と飼料要求率}

Table 5. Effect of tofu cake silage feeding on daily weight gain, feed intake and feed conversion ratio in growing pigs.

\begin{tabular}{lrccc}
\hline \hline & Week & $\begin{array}{c}\text { Daily weight } \\
\text { gain (kg) }\end{array}$ & $\begin{array}{c}\text { Feed intake } \\
(\mathrm{kg} / \text { head })\end{array}$ & $\begin{array}{c}\text { Feed conversion } \\
\text { ratio }\end{array}$ \\
\hline \multirow{3}{*}{ Control } & $1-3$ & $0.53 \pm 0.12^{2)}$ & 27.7 & 2.47 \\
& $4-12$ & $0.77 \pm 0.10$ & 148.6 & 3.06 \\
& $13-16$ & $0.85 \pm 0.06$ & 84.9 & 3.57 \\
& $1-16$ & $0.75 \pm 0.11$ & 261.2 & 3.13 \\
\hline \multirow{2}{*}{ Tofu cake } & $1-3$ & $0.59 \pm 0.15$ & 27.1 & 2.20 \\
silage 1 & $4-12$ & $0.74 \pm 0.07$ & 149.0 & 3.20 \\
& $13-16$ & $0.79 \pm 0.09$ & 90.6 & 4.10 \\
& $1-16$ & $0.72 \pm 0.09$ & 266.7 & 3.29 \\
\hline \multirow{2}{*}{ Tofu cake } & $1-3$ & $0.60 \pm 0.08$ & 27.1 & 2.15 \\
silage 2 & $4-14$ & $0.76 \pm 0.11$ & 188.6 & 3.22 \\
& $15-16$ & $0.74 \pm 0.14$ & 40.9 & 3.93 \\
& $1-16$ & $0.73 \pm 0.10$ & 256.6 & 3.14 \\
\hline
\end{tabular}

1) Air dry matter basis.

2) Values are means $\pm \mathrm{SEM}$ for 4 pigs.

表 6. 屠体測定值

Table 6. Effect of tofu cake silage feeding on backfat thickness in growing pigs.

$(\mathrm{cm})$

\begin{tabular}{lccc}
\hline \hline & Control & Tofu cake silage 1 & Tofu cake silage 2 \\
\hline Shoulder & $3.43 \pm 0.29^{\mathrm{al})}$ & $4.33 \pm 0.23^{\mathrm{b}}$ & $3.76 \pm 0.47^{\mathrm{ab}}$ \\
Midback & $1.60 \pm 0.20^{\mathrm{a}}$ & $2.19 \pm 0.33^{\mathrm{b}}$ & $1.69 \pm 0.30^{\mathrm{ab}}$ \\
Loin & $2.57 \pm 0.35^{\mathrm{a}}$ & $3.66 \pm 0.38^{\mathrm{b}}$ & $2.83 \pm 0.41^{\mathrm{ab}}$ \\
Mean & $2.52 \pm 0.29^{\mathrm{a}}$ & $3.39 \pm 0.27^{\mathrm{b}}$ & $2.77 \pm 0.38^{\mathrm{ab}}$ \\
\hline
\end{tabular}

1) Values are means \pm SEM for 4 pigs. Means with different superscript are significantly different at 5\% level of Duncan's Multiple Range Test. 
表 7. 脂肪融点

Table 7. Melting point of the back fat and leaf fat

$\left({ }^{\circ} \mathrm{C}\right)$

\begin{tabular}{lccc}
\hline \hline & Control & Tofu cake silage 1 & Tofu cake silage 2 \\
\hline Outer back fat & $28.3 \pm 1.3^{\mathrm{al}}$ & $24.5 \pm 1.6^{\mathrm{b}}$ & $25.7 \pm 1.2^{\mathrm{b}}$ \\
Inner back fat & $29.0 \pm 0.8^{\mathrm{a}}$ & $27.4 \pm 0.6^{\mathrm{ab}}$ & $26.8 \pm 0.6^{\mathrm{b}}$ \\
Kidney leaf fat & $40.1 \pm 1.2^{\mathrm{a}}$ & $37.1 \pm 1.0^{\mathrm{b}}$ & $33.8 \pm 1.8^{\mathrm{c}}$ \\
\hline
\end{tabular}

1) Values are means $\pm \mathrm{SEM}$ for 4 pigs. Means with different superscript are significantly different at 5\% level of Duncan's Multiple Range Test.

表 8. 体脂肪の脂肪酸組成

Table 8. Fatty acid composition of the back and kidney leaf fat.

\begin{tabular}{|c|c|c|c|c|}
\hline & Fatty acid & Control & $\begin{array}{l}\text { Tofu cake } \\
\text { silage } 1\end{array}$ & $\begin{array}{c}\text { Tofu cake } \\
\text { silage } 2\end{array}$ \\
\hline \multirow{7}{*}{ Outer back fat } & $\mathrm{C} 14: 0$ & $1.0 \pm 0.1^{1)}$ & $0.6 \pm 0.1$ & $0.8 \pm 0.2$ \\
\hline & C $16: 0$ & $22.6 \pm 1.1^{\mathrm{a}}$ & $19.9 \pm 0.7^{\mathrm{b}}$ & $19.8 \pm 1.0^{\mathrm{b}}$ \\
\hline & $\mathrm{C} 16: 1$ & $3.8 \pm 0.5^{\mathrm{a}}$ & $2.3 \pm 0.3^{\mathrm{b}}$ & $2.4 \pm 0.3^{\mathrm{b}}$ \\
\hline & C $18: 0$ & $12.4 \pm 1.0$ & $11.3 \pm 1.0$ & $11.2 \pm 1.0$ \\
\hline & C $18: 1$ & $49.9 \pm 1.4^{\mathrm{a}}$ & $43.5 \pm 1.0^{\mathrm{b}}$ & $44.7 \pm 2.0^{\mathrm{b}}$ \\
\hline & C $18: 2$ & $9.1 \pm 0.9^{\mathrm{a}}$ & $19.8 \pm 1.3^{b}$ & $18.4 \pm 1.0^{\mathrm{b}}$ \\
\hline & C $18: 3$ & $1.2 \pm 0.2^{\mathrm{a}}$ & $2.6 \pm 0.5^{\mathrm{b}}$ & $2.7 \pm 0.5^{\mathrm{b}}$ \\
\hline \multirow{7}{*}{ Inner back fat } & $\mathrm{C} 14: 0$ & $0.8 \pm 0.1$ & $0.8 \pm 0.2$ & $0.9 \pm 0.2$ \\
\hline & $\mathrm{C} 16: 0$ & $24.4 \pm 1.3^{\mathrm{a}}$ & $21.0 \pm 0.7^{\mathrm{b}}$ & $20.2 \pm 1.2^{\mathrm{b}}$ \\
\hline & C $16: 1$ & $2.6 \pm 0.4^{\mathrm{a}}$ & $1.6 \pm 0.2^{\mathrm{b}}$ & $1.9 \pm 0.3$ \\
\hline & C 18:0 & $15.7 \pm 0.6$ & $14.2 \pm 0.9$ & $13.4 \pm 0.5$ \\
\hline & C $18: 1$ & $47.3 \pm 1.5^{\mathrm{a}}$ & $43.6 \pm 1.0^{\mathrm{b}}$ & $41.3 \pm 1.4^{b}$ \\
\hline & C $18: 2$ & $8.1 \pm 0.5^{\mathrm{a}}$ & $16.5 \pm 1.1^{\mathrm{b}}$ & $18.7 \pm 0.9^{b}$ \\
\hline & C $18: 3$ & $1.0 \pm 0.1^{\mathrm{a}}$ & $2.3 \pm 0.3^{b}$ & $3.6 \pm 0.4^{\mathrm{b}}$ \\
\hline \multirow{7}{*}{ Kidney leaf fat } & C 14:0 & $1.5 \pm 0.4$ & $0.8 \pm 0.2$ & $0.9 \pm 0.1$ \\
\hline & $\mathrm{C} 16: 0$ & $27.9 \pm 0.9^{\mathrm{a}}$ & $23.2 \pm 1.1^{\mathrm{b}}$ & $22.7 \pm 1.4^{\mathrm{b}}$ \\
\hline & $\mathrm{C} 16: 1$ & $2.3 \pm 0.5$ & $1.8 \pm 0.3$ & $2.4 \pm 0.4$ \\
\hline & C 18:0 & $17.4 \pm 0.6$ & $17.9 \pm 0.6$ & $16.0 \pm 0.7$ \\
\hline & C $18: 1$ & $42.5 \pm 1.3$ & $40.6 \pm 1.1$ & $39.8 \pm 1.5$ \\
\hline & $\mathrm{C} 18: 2$ & $7.5 \pm 0.6^{\mathrm{a}}$ & $13.6 \pm 1.0^{\mathrm{b}}$ & $16.2 \pm 0.9^{c}$ \\
\hline & C $18: 3$ & $0.9 \pm 0.2^{\mathrm{a}}$ & $2.1 \pm 0.3^{b}$ & $2.0 \pm 0.2^{\mathrm{b}}$ \\
\hline
\end{tabular}

1) Values are means \pm SEM for 4 pigs. Means with different superscript are significantly different at $5 \%$ level of Duncan's Multiple Range Test.

と報告している。本試験において，豆腐粕サイレージ 1 区は出荷 4 週間前よりサイレージの給与を中止している が，豆腐粕サイレージ 2 区はサイレージ給与量を 4 14 週まで $50 \%$ に制限しているあのの出荷 2 週間前まで給 与を続けたことによると思われる。

背脂肪及び腎臟周囲脂肪中の脂肪酸組成については表 8 に示した。背脂肪外層において豆腐粕サイレージ 1 区
は対照区と比べ $16: 0, \mathrm{C} 16: 1$ および $\mathrm{C} 18: 1$ が有意に 低く，C18: 2 および $\mathrm{C} 18: 3$ が有意に高くなり，豆腐粕 サイレージ 2 区むほぼ同様の傾向を示した。背脂肪内層 は各区とも外層に比べ飽和脂肪酸が高かったが，サイ レージ給与区では対照区に比べいずれあ $\mathrm{C} 16: 0$ および $\mathrm{C} 18: 1$ が有意に低く, C18: 2 および $\mathrm{C} 18: 3$ が高い值を 示した。腎臓周囲脂肪においても，おおむね背脂肪の結 
$1995 ， 3$ 月

果と同様の傾向を示したが，豆腐粕サイレージ 2 区の C 18：1 は対照区より少ないものの有意な差を示さなかっ た。サイレージ中の脂肪酸組成は対照区飼料と大きな差 は認められなかったが, 体脂肪中の $\mathrm{C} 18: 2$ は測定した すべての部位で対照区の約 2 倍を含有していた。このこ とは, 飼料中の $\mathrm{C} 18: 2$ が他の脂肪酸に比べ選択的に蓄 積されやすい(2) ことを示している。しかし，代替率の高 い豆腐粕サイレージ 1 区でむ屠殺前 4 週間の給与停止に より腎臟周囲脂肪では豆腐粕サイレージ 2 区に比べ融点 の上昇が認められた。従って, サイレージの多給は脂肪 の融点や脂肪酸組成に影響を及ぼすすのの, 給与時期や 方法の検討により，ある程度影響を減ずることも可能と 考えられ，今後さらに検討を行う必要があろう。

近年，消費者は食品の機能に強い関心を示しており， 飽和脂肪酸の過剩攝取が成人病の原因となることや不飽 和脂肪酸の効果に関する認識も浸透している。この様な 状況において, 豚肉の品質や脂肪酸組成についても従来 と異なる基準によって評価される可能性むあり, 本試験 におけるサイレージ給与区の枝肉も高リノール酸 (C18:

2）含有豚肉といった販売法も考えられる。

以上のことから，肥育豚に対するサイレージの給与は 脂肪酸組成に影響を及ぼすものの発育に大きな差は認め られず，飼料費削減に有効と思われた。

\section{謝辞}

稿を終えるにあたり，統計処理その他に貴重な助言を
日豚会誌 32 巻 1 号

賜った本学動物育種学研究室, 泉水直人助教授に深く感 謝致します。

\section{文献}

1）丹羽美次 - 中西五十・栗田隆之：日豚会誌，30, 128-134, 1993.

2）柴田寛三 : 新生物統計学序説，88-101, 創文, 東 京, 1989 .

3）農林水産省農林水産技術会議事務局編：日本飼養 標準, 豚（1975 年版）中央畜産会, 1975.

4）日本種豚登録協会編：豚産肉能力検定実務書, 1979.

5）森本 宏（監修）：動物栄養試験法, 養賢堂, 280298, 1971

6) Mateos, G.G., and J.L. Sell : Poultry Sci., 59, 2129-2135, 1980.

7) Allee, G.L., D.R. Romsos, G.A. Leveille and D. H. BAKER : J. Anim. Sci., 35, 41-47. 1972.

8) SeERley, R.W., J.P. BRISCOF and H.C. Mc CAMPBELl : J. Anim. Sci., 46, 1018-1023. 1978.

9）大武由之 - 中里孝之・斎藤 馨 - 佐藤清之 - 谷田 部治之・高橋光輝・岸本赴夫 : 日畜会報, 41 , 407-413, 1970.

10) Villegas, F.J., H.B. Hedrick, T.L. Veum, K.L. McFAte and M.E. Bailey : J. Anim. Sci., 36, 633-668. 1973.

11）入江正和 - 藤谷泰裕 : 日豚会誌， 26，255-260, 1989.

12） BRooks, C.C., : J. Anim. Sci., 33, 1224-1230. 1971. 


\title{
Research on the Utilization of Food By-Product to Growing and Finishing Pigs.
}

\section{The Effects of Tofu Cake Silage Feeding on Growth and Body Fat}

\author{
Yoshitugu Niwa and Goto NAKanisı
}

Department of Animal Science, Nihon University, Fujisawa-shi, 252

The fattening and digestion trials were carried out in crossbred pigs by feeding ensiled tofe cake silage with $13.7 \%$ of ground barly and $0.7 \%$ of vitamin, mineral premix. In the first trial, $50 \mathrm{~kg}$ of LW crossbred pigs were fed for 5 days either with ensiled tofu cake silage or with a basal diet, in the control condition, containing maize $73.3 \%$, soybean meal $12 \%$, barly $10 \%$, fish meal $2.6 \%$, and others $2.1 \%$. There were no significant differences in the digestibility of crude protein, crude fat or of NFE between tofu cake silage condition and the control condition. However, the digestibility of crude fiber was significantly higher in the tofu cake silage condition than in the control condition.

Three experimental groups of LWH crossbred pigs were placed on the fattening trial for 16 weeks. Group 1 was supplied with the control diet throughout the trial term. Group 2 was supplied with $100 \%$ tofu cake silage during the first 12 weeks and then was supplied with the $100 \%$ control diet from the 13 th through 16 th week (tofu cake silage 1 ). Group 3 fed $100 \%$ tofu cake silage during the first 3 weeks, $50 \%$ tofu cake silage and $50 \%$ experimental diet, which contained barley in stead of soy bean meal in the control diet, for the 4 th through 13 th weeks, and $100 \%$ control diet was fed for the last 2 weeks (tofu cake silage 2). There were no significant differences in the average daily gain among three groups at any stage of the trial. In tofu cake silage 1 and $2,66 \%$ and $47 \%$ of the total diet were substituted with tofu cake silage, respectively. No differences among the three groups in feed convertion ratio were found throughout the experimental term. High palatability of the tofu cake silage was observed in the pigs. After the fattening trial, melting points of back and kidney leaf fat were either significantly lower or tended to be lower in the pigs fed with the tofu cake silage compared to those in the control diet. Silage feeds caused a higher concentration of linoleic acid and linolenic acid, but the concentration of palmitic acid was lowered.

The tofu cake silage led to normal growth, and an increase in unsaturated fatty acid, and to lower melting points of body fat in fattening pigs.

Jpn. J. Swine Science, 32, $1: 1-7$

Key words : Tofu cake, silage, growth, fatty acid composition 